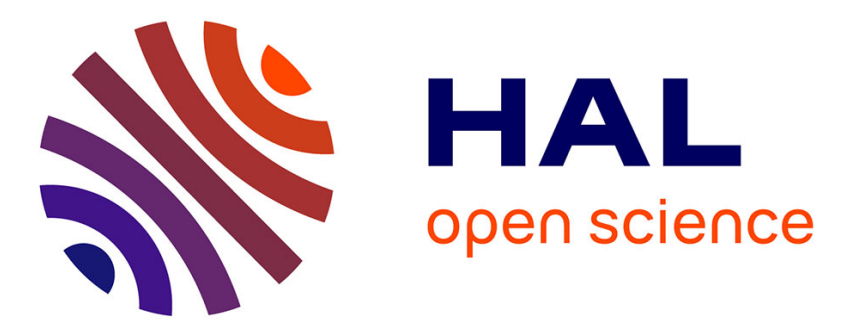

\title{
First record of a non-pollinating fig wasp (Hymenoptera: Sycophaginae) from Dominican amber, with estimation of the size of its host figs
}

Fernando Farache, Jean Yves Rasplus, Dany Azar, Rodrigo A. S. Pereira, Stephen G. Compton

\section{To cite this version:}

Fernando Farache, Jean Yves Rasplus, Dany Azar, Rodrigo A. S. Pereira, Stephen G. Compton. First record of a non-pollinating fig wasp (Hymenoptera: Sycophaginae) from Dominican amber, with estimation of the size of its host figs. Journal of Natural History, 2016, 50 (35-36), pp.2237 - 2247. 10.1080/00222933.2016.1193646 . hal-01602442

\section{HAL Id: hal-01602442 \\ https://hal.inrae.fr/hal-01602442}

Submitted on 25 May 2021

HAL is a multi-disciplinary open access archive for the deposit and dissemination of scientific research documents, whether they are published or not. The documents may come from teaching and research institutions in France or abroad, or from public or private research centers.
L'archive ouverte pluridisciplinaire HAL, est destinée au dépôt et à la diffusion de documents scientifiques de niveau recherche, publiés ou non, émanant des établissements d'enseignement et de recherche français ou étrangers, des laboratoires publics ou privés. 


\section{UNIVERSITY OF LEEDS}

This is a repository copy of First record of a non-pollinating fig wasp (Hymenoptera: Sycophaginae) from Dominican amber, with estimation of the size of its host figs.

White Rose Research Online URL for this paper:

http://eprints.whiterose.ac.uk/103701/

Version: Accepted Version

\section{Article:}

Farache, FHA, Rasplus, JY, Azar, D et al. (2 more authors) (2016) First record of a non-pollinating fig wasp (Hymenoptera: Sycophaginae) from Dominican amber, with estimation of the size of its host figs. Journal of Natural History, 50 (35-36). pp. 2237-2247. ISSN 0022-2933

https://doi.org/10.1080/00222933.2016.1193646

(C) 2016 Informa UK Limited, trading as Taylor \& Francis Group. This is an author produced version of a paper published in Journal of Natural History. The version of record of this manuscript has been published and is available in http://dx.doi.org/10.1080/00222933.2016.1193646. Uploaded in accordance with the publisher's self-archiving policy.

\section{Reuse}

Unless indicated otherwise, fulltext items are protected by copyright with all rights reserved. The copyright exception in section 29 of the Copyright, Designs and Patents Act 1988 allows the making of a single copy solely for the purpose of non-commercial research or private study within the limits of fair dealing. The publisher or other rights-holder may allow further reproduction and re-use of this version - refer to the White Rose Research Online record for this item. Where records identify the publisher as the copyright holder, users can verify any specific terms of use on the publisher's website.

\section{Takedown}

If you consider content in White Rose Research Online to be in breach of UK law, please notify us by emailing eprints@whiterose.ac.uk including the URL of the record and the reason for the withdrawal request. 


\section{First record of a non-pollinating fig wasp (Hymenoptera:}

\section{Sycophaginae) from Dominican amber, with estimation of the size of}

\section{its host figs}

Fernando H. A. Farache ${ }^{1}$, Jean-Yves Rasplus ${ }^{2}$, Dany Azar ${ }^{3}$, Rodrigo A. S. Pereira $^{1}$, Stephen G. Compton ${ }^{4,5}$

${ }^{1}$ PPG em Entomologia, Departamento de Biologia, Faculdade de Filosofia, Ciências e Letras de Ribeirão Preto, Universidade de São Paulo, Ribeirão Preto, SP, Brazil. FHAF: fhafarache@gmail.com RASP:raspereira@ffclrp.usp.br.

${ }^{2}$ INRA, UMR 1062 CBGP Montferrier-sur-Lez,France.rasplus@supagro.inra.fr.

${ }^{3}$ Lebanese University, Faculty of Sciences II, Department of Biology, Fanar Matn, Lebanon azar@mnhn.fr.

${ }^{4}$ School of Biology, University of Leeds, Leeds LS2 9JT, UK.

s.g.a.compton@leeds.ac.uk.

${ }^{5}$ Department of Zoology and Entomology, Rhodes University, Grahamstown 6140, South Africa.s.compton@ru.ac.za.

Corresponding author: Fernando Henrique Antoniolli Farache, Departamento de Biologia, FFCLRP-USP Ribeirão Preto SP, Brazil.fhafarache@gmail.com.

This work was supported by the FAPESP (Grants \#2010/51158-5, \#2012/19815-1 \& \#2015/06430-2) and by CNPq (\#306078/2014-7). 


\section{First record of a non-pollinating fig wasp (Hymenoptera: \\ Sycophaginae) from Dominican amber, with estimation of the size of its host figs}

Fig trees and their pollinating fig wasps arose about 75 million years ago in the Cretaceous period. Several other groups of chalcid wasps also utilize figs for larval development, including sycophagines, the putative sister group to pollinating fig wasps. Whereas stone and amber fossil pollinators are known, no fossils representing non-pollinating fig wasp groups have been confirmed previously. Here, we describe the first Sycophaginae from the $c 15-20 \mathrm{Ma}$ Dominican amber, Idarnes thanatos sp. nov. Farache, Rasplus, Pereira and Compton, and discuss its relationships within the Idarnes carme species group. Additionally, we use linear regression to compare body size, ovipositor sheaths length, and host fig size data from extant Idarnes species to estimate the size of its host figs. Idarnes thanatos was most likely associated with small to medium sized figs (diameter $\leq 1.0 \mathrm{~cm}$ ), that were likely to have been dispersed by birds and primates. The discovery of this close relative of extant non-pollinating fig wasps suggests that early Miocene and modern fig wasp communities may share similar ecological and functional features.

Keywords: Agaonidae, Chalcidoidea, Ficus, fossil insect communities, Miocene, palaeoecology. 


\section{Introduction}

The association between fig trees (Moraceae, Ficus) and their pollinating fig wasps (Chalcidoidea, Agaonidae, Agaoninae) is one of the most renowned examples of plant-insect mutualisms (Cook and Rasplus 2003, Kjellberg et al. 2005). Fig trees and their pollinating wasps probably arose about 75 million years ago in the Cretaceous period (Cruaud et al. 2012) and subsequently diversified to generate the $750+$ fig tree species and more than 1000 pollinator species present today (Berg and Corner 2005). Figs (syconia) are enclosed hollow inflorescences lined with many tiny flowers. Adult female pollinator fig wasps enter receptive figs through a small apical pore, called the ostiole, in order to lay their eggs inside some of the female flowers (Galil and Eisikowitch 1968). They show several morphological adaptations that allow them to enter the figs, carry pollen, and pollinate, including a modified head, antennae and mandibular appendages, and those species that actively pollinate also have pollen pockets and coxal combs (Ramírez 1974, 1978, Cook and Rasplus 2003).

Apart from pollinating fig wasps, several other lineages of Chalcidoidea utilize figs as oviposition sites, but only a very few species pollinate the fig flowers and so their relationship with Ficus is antagonistic rather than mutualistic. These lineages are known as non-pollinating fig wasps (NPFW). Most species have long exerted or coiled ovipositors that allow them to lay their eggs from the outside of the figs, but some NPFW enter the figs to lay their eggs. According to the latest phylogenetic analyses (Heraty et al. 2013), most of the NPFW subfamilies that were at one time placed in Agaonidae are now assigned to Pteromalidae, while the Sycophaginae are recognized as one subfamily of Agaonidae, together with the pollinating fig wasps. 
Among the six subgenera of Ficus, the Sycophaginae NPFWs are strictly associated with Ficus subgenera Sycomorus and Urostigma. Molecular clock analyses suggest that Sycophaginae may have originated in the Palaeocene (50-40 Ma), after the break-up of Gondwana (Cruaud et al. 2011a), but they have subsequently achieved a pantropical distribution. There are only about 60 species of Sycophaginae described to date, but the real diversity of the group is hard to estimate due to the high number of undescribed species found in recent studies (Cruaud et al. 2011b, Farache et al. 2013, Farache and Rasplus 2014).

Within Sycophaginae, Idarnes is the second most speciose genus, with 23 species described from the Americas, and forms the most conspicuous group of NPFWs in the Neotropical region (Gordh 1975, Bouček 1993, West and Herre 1994). Idarnes is associated with Ficus subgenus Urostigma, section Americana and is divided into three monophyletic (Cruaud et al. 2011a, Cruaud et al. 2011b) and morphologically recognizable (Bouček 1993) species-groups, namely the I. carme, I. flavicollis and I. incertus sp. gps. In addition to their morphological divergence, these species groups show different life history strategies and larval feeding habits (Cruaud et al. 2011b, Elias et al. 2012).

Species belonging to the I. incertus sp. gp. are larger than co-occurring pollinator fig wasps and have relatively shorter ovipositors. They arrive early during fig development and probably induce galls in the fig receptacles (Bronstein 1999). Species belonging to the I. flavicollis sp. gp. are about the same size or slightly larger than pollinators and their ovipositors are longer than those of pollinators and other cooccurring species. They arrive at the same time as pollinators, induce galls in fig pistilate flowers, and probably compete with pollinators for oviposition sites (Elias et 
al. 2012). Members of the I. carme sp. gp. are about the same size as pollinators with relatively longer ovipositors (but usually shorter than in the I. flavicollis sp. gp.). They arrive after pollination and are probably cleptoparasites that kill pollinators (Elias et al. 2012).

Within non-sycophagine Agaonidae, three fossil pollinator species have been described from Dominican amber (Mid Miocene) (Peñalver et al. 2006): Tetrapus apopnus Peñalver and Engel, 2006; Tetrapus delclosi Peñalver and Engel, 2006; and Pegoscapus peritus Peñalver and Engel, 2006, but additional undescribed species are known (J-Y. Rasplus, unpubl. data). Archaeagaon minutum (Donisthorpe, 1920) was collected from the Isle of Wight Insect Limestone (Late Eocene) and although originally described as an ant (Ponera), is clearly a pollinating fig wasp (Compton et al. 2010, Antropov et al. 2014). Much less evidence of fossil NPFW is available. Parviformosus wohlrabeae Barling, Heads and Martill, 2013 was described from the lower Cretaceous of Brazil and was considered as a possible sycophagine, based in part on its long ovipositor (Barling et al. 2013). However, P. wohlrabeae lacks the apomorphic characters that could place it in Chalcidoidea and whether it is truly a fig wasp remains to be demonstrated. No other putative NPFW have been described.

In this paper we describe the first confirmed fossil NPFW as Idarnes thanatos sp. nov based on a single female from Dominican amber. Based on its morphology and comparisons with extant Idarnes and Ficus species we also estimate the size of the figs where it laid its eggs, from which we infer the plant's likely seed dispersal agents. 


\section{Materials and methods}

\section{Dominican amber and specimen preparation}

The Dominican amber has been dated as Mid-Miocene (15-20 million years ago) and its resin is probably derived from a single extinct Hymenaea (Papilionaceae) species (Iturralde-Vinent and MacPhee 1996). The specimen was acquired from a commercial source by S. G. Compton and prepared at Muséum National d'Histoire Naturelle in Paris, by D. Azar. According to the suppliers, the specimen was excavated in the La Bucara amber mines in 2008. The amber piece included the described specimen, one large leaf/leaflet, an ant specimen (Formicidae) and another chalcid wasp (Supplementary file 1).

Protocols for imaging and description mostly followed Farache and Rasplus (2014). Morphological terminology follows Gibson (1997) and the HAO portal (Yoder et al. 2010). The specimen was photographed using a Leica M16 zoom lens attached to a JVC KY-75U 3CCD digital camera and a portable computer workstation running EntoVision Imaging Suite software (GT Vision, Hagerstown, MD USA). Cartograph 5.6.0 (Microvision, Evry, France) software was subsequently used to merge the image series. Illumination was achieved using a 'quadrant' setup, with four fibre optic light guides stemming from two individual light sources (Leica CLS $150 \mathrm{X}$ ), similar to the method described by Buffington and Gates (2008). 


\section{Abbreviations and acronyms}

Abbreviations for measurements include: $L=$ length; $W=$ width; $H=$ height; $F_{x}=$ funicular segment $\mathrm{x}, \mathrm{FD}=$ fig diameter, $\mathrm{BL}=$ body length, $\mathrm{OL}=$ ovipositor sheaths length, and $\mathrm{OB}=$ ratio of ovipositor sheaths/body length.

Acronyms for specimen depositories and their respective curators include:

MZSP: $\quad$ Brazil, São Paulo, São Paulo, Museu de Zoologia da Universidade de São Paulo (Carlos Roberto Ferreira Brandão).

CBGP: $\quad$ France, Montferrier-sur-Lez. Centre de Biologie pour la Gestion des Populations (Emmanuelle Artige).

\section{Estimation of host fig size}

We recorded body length (BL), ovipositor sheaths length (OL), and the ratio of ovipositor sheaths/body length (OB) for 11 described Idarnes species and 20 undescribed species. Since differences in life histories in Sycophaginae are related to morphological characters such as body size and ovipositor length (Cruaud et al. 2011b) we restricted the analysis to species that were in the species group to which $I$. thanatos can be assigned (Idarnes carme sp. gp. sensu Bouček (1993), as explained below). The specimens analysed are deposited in the Jean-Yves Rasplus collection at CBGP (France) and the Rodrigo A. S. Pereira collection at USP Ribeirão Preto (Brazil.) Body measures were taken from 31 wasp species, with a total of 136 specimens measured. Measures were mostly taken from three to six specimens per species. When fewer or no specimens were available, we measured all available specimens or took the information from the literature (Gordh 1975; see Supplementary File 2 for further information on specimen sampling). The fig wasps 
were photographed using a Leica MZ16 stereomicroscope and measured with ImageJ software (Abràmoff et al. 2004) and Leica application suite V3.6.

Fig diameters (FD) for each species were taken from the literature (Burger 1977, Berg and Villavicencio 2004, Berg 2009). These references cited the maximum and minimum fig diameter, and therefore we took the median of these values (excluding outlier values when they were present in the descriptions). Measurements of wasps and figs are recorded in Supplementary file 2.

We performed linear regressions using the following models: BL FD, OL FD, and OB FD. These regressions were performed using both maximum and median fig sizes as predictors. In order to select the best-fitting model, we compared the $\mathrm{R}^{2}$ regression index among the models and used the best-fitting model to predict the $95 \%$ confidence interval of fig diameter using the characteristics of the fossil specimen. The graphic regression diagnostics, Quantile-Quantile plots, and distribution of residuals for the estimated models confirmed that there was no violation of linear model assumptions. All analyses were performed using the R statistical environment (R Core Team 2015).

\section{Results}

\section{Systematic palaeontology}

Order HYMENOPTERA Linnaeus, 1758

Suborder APOCRITA Gerstaecker, 1867

Superfamily CHALCIDOIDEA Latreille, 1817

Family AGAONIDAE Walker, 1846 
Subfamily SYCOPHAGINAE Walker, 1875

Idarnes Walker, 1843

Idarnes thanatos Farache, Rasplus, Pereira and Compton, sp. nov.

urn:1sid:zoobank.org:act:0A8B0B2A-3E43-4516-AA2D-CBC390BFB385

Fig. 1

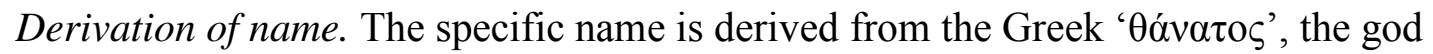
of death, in reference to it being an extinct taxon.

\section{Diagnosis}

Body colour mostly black, with faint metallic reflection. Antenna with two anelli.

Supraclypeal area wider than torulus diameter. Mesoscutum and mesoscutellum reticulate. Postmarginal vein $1.2 \mathrm{x}$ as long as stigmal vein. Ovipositor sheaths $1.1 \mathrm{x}$ as long as body.

\section{Description}

Size and colour. Body length (excluding ovipositor) $1.1 \mathrm{~mm}$. Length of ovipositor sheaths $1.2 \mathrm{~mm}$. Body colour mostly black, with faint metallic reflection, mostly green and orange, at least on mesosoma in dorsal view. Antennae dark brown. Legs yellow brown. Wings hyaline, submarginal vein dark brown, marginal, postmarginal, and stigmal veins light brown.

Head. Antenna with 13 antennomeres including two anelli; antennal formula 11263. 
Scape $1.4 \mathrm{x}$ as long as pedicel. Funicular segments $1.0-1.4 \mathrm{x}$ as long as wide. Clava well delimited, with three laterally compressed flagellomeres (compression probably related to post mortem alteration). Antennae inserted just above the lower line of compound eyes. Head transverse, $1.3 \mathrm{x}$ as wide as high. Head sculpture reticulated, at least close to vertex. Supraclypeal area wider than torulus diameter. Clypeal margin unilobed.

Mesosoma. Pronotum longer than high in lateral view. Mesoscutum and mesoscutellum reticulate. Notauli complete. Mesoscutellar-axillar complex with straight axillular grooves and transverse frenal sulcus, delimitating a square mesoscutellum. Mesoscutellum $1.1 \mathrm{x}$ as long as wide. Propodeum length $3.5 \mathrm{x}$ propodeal spiracle diameter. Postmarginal vein $1.2 \mathrm{x}$ as long as stigmal vein. Protibia with a bifurcated tibial inner spur. Metatibia with two tibial inner spurs.

Metasoma. Suboval. Ovipositor sheaths $1.1 \mathrm{x}$ as long as body. Ovipositor teeth concentrated at the distal extremity of ovipositor. Teeth heterogeneously distributed and of variable length, shorter at the tip of the ovipositor.

Measurements (mm). Head: L 0.13 W 0.28 H 0.22; Mesosoma L 0.47; Metasoma $L$ 0.51. Scape $L 0.17$; Pedicel $L 0.05 ; \mathrm{F}_{1} L 0.03 W 0.03 ; \mathrm{F}_{2-6} L 0.04 W 0.03$; Clava $L$ $0.11 W 0.05$; Eye $L 0.18 H 0.22$; Profemur $L 0.2 W 0.05$; Protibia $L 0.15 W 0.03$; Protibial inner spur $L$ 0.05; Metafemur $L 0.18 W 0.05$; Metatibia $L 0.17$ W 0.03; Metatibial inner spur 1 L 0.04; Metatibial inner spur $2 L 0.03$.

Remarks. The (unnamed) specimen was used previously in Cruaud et al. (2011a) for calibration of a molecular clock analysis. Idarnes thanatos sp. nov. belongs to the $I$. carme species-group, based on the following characters: 1) postmarginal vein longer than stigmal vein, 2) ovipositor longer than body, 3) clypeal margin unilobed 4) head 
sculpturation heterogeneous (but visualization of this character was difficult due to the preservation of the fossil), and 5) ovipositor teeth concentrated at the distal extremity of the ovipositor, with a heterogeneous distribution and of variable length. We are confident that I. thanatos sp. n. does not belong to any known extant Idarnes species. This putatively extinct species can be easily distinguished from other known Idarnes carme sp. gp. species by a combination of characters: 1) the presence of two anelli (rather than one) and 2) its relatively short ovipositor.

HOLOTYPE: Female, MZSP, amber from the Dominican Republic. The specimen occurs in a small, clear piece of amber measuring $3.9 \mathrm{~mm}$ in length, $2.5 \mathrm{~mm}$ in height, and $1.5 \mathrm{~mm}$ in width (thickness). The amber piece is attached to a glass holder and mounted on an entomological pin to facilitate handling and image acquisition. The specimen is deposited in the Hymenoptera collection at Museu de Zoologia, Universidade de São Paulo, São Paulo, Brazil.

\section{Estimation of host fig size}

Body characters and fig diameter across extant Idarnes species and their hosts were positively correlated $\left(\mathrm{R}^{2}=0.68-0.76, P \leq 10^{-8}\right.$, Table 1$)$. This pattern was also observed when we used maximum fig size instead of median fig sizes, which confirmed the robustness of the median as a measure of size. Ovipositor sheath length was the body character best explained by fig diameter (Table 1, Fig. 2). The fitted value of median fig diameter for the ovipositor sheath length of I. thanatos sp. nov. $(\mathrm{OL}=1.2 \mathrm{~mm})$ was $0.61 \mathrm{~cm}\left(\mathrm{IC}_{95 \%}=0.22-1.01 \mathrm{~cm}\right)($ Fig. 2$)$. Among the 31 studied fig wasp species, 20 occurred in figs with the same diameter range as the $95 \%$ confidence interval calculated for the diameter of the putative host of I. thanatos, and 
comprised the Ficus americana and $F$ aurea complexes, some varieties of the $F$. pertusa complex, F. citrifolia, F. cestrifolia, F. colubrinae, F. eximia, F. hartwegii and F. mariae. More specifically, the body length and ovipositor sheath length of $I$. thanatos are similar to those of three Idarnes species currently associated with the $F$. americana complex.

\section{Discussion}

Palaeontological data obtained from fig wasps is scarce, because so few extinct species have been described, and this has limited the insights they can provide into the evolution of the fig tree-fig wasp system (Peñalver et al. 2006, Compton et al. 2010). Non-pollinating fig wasps are far more diverse and species-rich than pollinators in current fig wasp communities (Compton et al. 1994, Marussich and Machado 2007, Segar et al. 2013). The only putative non-pollinating fig wasp that has been described

previously (Barling et al. 2013) does not exhibit any apomorphic characters that confirm it as a chalcid wasp. This makes Idarnes thanatos sp. nov. the first confirmed fossil representative of the non-pollinator fig wasps that are so diverse in figs today.

The I. carme species-group is the most speciose group of Idarnes (Gordh 1975, Cruaud et al. 2011b). They are known to occur throughout most of the distribution of Ficus section Americana, from southern Brazil to Florida (Gordh 1975). Since they are unable to develop without the pollinator Pegoscapus Cameron, they are probably cleptoparasites of this genus of pollinating fig wasps (Elias et al. 2012). Species belonging to this group can be host specific, but some utilize several co-occurring host species (Farache et al. unpublished data; Marussich and Machado 2007). This group was retrieved as monophyletic and sister to the other Idarnes species-groups in 
a global phylogenetic analyses of Sycophaginae (Cruaud et al. 2011b). The molecular clock analyses that used I. thanatos as a calibration point (Cruaud et al. 2011a) estimated Idarnes to have originated 29.2-18.2 Ma. According to this analysis, Idarnes probably arose after the break-up of Gondwanaland, between the Oligocene and Miocene (Cruaud et al. 2011a), a conclusion consistent with its New World distribution. Dominican amber cannot be dated accurately, but I. thanatos clearly dates to a period close to the origins of the genus, and indicates that distinct species groups, with differing ecologies, had already diverged by that time. Recent analyses suggested that the ovipositor morphology is correlated with feeding regime (Elias 2013) in Idarnes species. Idarnes thanatos' ovipositor shows heterogeneously spaced teeth that are shorter near the tip of the ovipositor. This observation is consistent with other morphological features of the I. carme sp. gp, and strongly suggests that $I$. thanatos was a cleptoparasite, probably feeding on resources of pollinating fig wasps (Elias 2013)

Correlations between fig wasp morphology and host plant characters are well documented in figs and fig wasps (van Noort and Compton 1996, Kjellberg et al. 2001, Weiblen 2004). For species that oviposit from the outside of figs, the lengths of their ovipositors reflect the size of the figs at the time that they oviposit, which varies depending on their host species, and the stage of fig development when oviposition takes place (Zhen et al. 2005, Ghara and Borges 2010). Larger figs tend to have thicker walls, and consequently in larger figs the ovules in which most fig wasps develop are located further from the outer surface. Longer ovipositors are therefore required.

Our regression analyses found a strong relationship between ovipositor sheath length 
and host fig diameter. Based on comparisons using extant fig tree species and their associated Idarnes wasps, Idarnes thanatos was associated with a small to mediumsized fig with a diameter between 0.2 and $1.0 \mathrm{~cm}$. Measurements taken of I. thanatos were most similar to those of a modern Idarnes species associated with figs of Ficus americana Aubl. (Supplementary file 2), suggesting that the host fig of I. thanatos was of similar size. Ficus americana figs are eaten by a range of vertebrate frugivores, including doves, passerine birds and primates (Shanahan et al. 2001). The host fig tree of I. thanatos may or may not be extinct, but a rather different assemblage of vertebrate species from a similar guild are likely to have been dispersing its seeds at the time when this particular individual became trapped in amber (Herrera 1985).

\section{Acknowledgements}

We thank Gunther Fleck for invaluable help and guidelines for imaging and specimen preparation. FHAF was supported by FAPESP (\#2010/51158-5, \#2012/19815-1 and \# 2015/06430-2). RASP was supported by CNPq (\#306078/2014-7).

\section{References}

Abràmoff MD, Magalhães PJ, Ram SJ. 2004. Image Processing with ImageJ. Bioph Int. 11:36-42.

Antropov AV, Belokobylskij SA, Compton SG, Dlussky GM, Khalaim AI, Kolyada VA, Kozlov MA, Perfilieva KS, Rasnitsyn AP. 2014. The wasps, bees and ants (Insecta: Vespida $=$ Hymenoptera) from the Insect Limestone (Late Eocene) of the Isle of Wight, UK. Earth and Environmental Science Transactions of the Royal Society of Edinburgh. 104:335-446. 
Barling N, Heads SW, Martill DM. 2013. A new parasitoid wasp (Hymenoptera:

Chalcidoidea) from the Lower Cretaceous Crato Formation of Brazil: The first Mesozoic Pteromalidae. Cretaceous Res. 45:258-264.

Berg CC. 2009. 27B. Moraceae (Ficus). In: Flora of Ecuador. Göteborg, Sweden:

Department of Plant and Environmental Sciences, University of Gothenburg.

p. $1-148$.

Berg CC, Corner EJH. 2005. Moraceae - Ficus. Flora Malesiana Series I (Seed Plants)

Leiden: National Herbarium of the Netherlands.

Berg CC, Villavicencio X. 2004. Taxonomic studies on Ficus (Moraceae) in the West Indies, extra-amazonian Brazil, and Bolivia. Ilicifolia. 5:1-132.

Bouček Z. 1993. The genera of chalcidoid wasps from Ficus fruit in the New World. J Nat Hist. 27:173-217.

Bronstein JL. 1999. Natural history of Anidarnes bicolor (Hymenoptera: Agaonidae), a galler of the Florida strangling fig (Ficus aurea). Florida Entomologist. $82: 454-461$.

Buffington ML, Gates MW. 2008. Advanced imaging techniques II: using a compound microscope for photographing point-mount specimens. Am Entomol. 54:222-224.

Burger W. 1977. Family \#52, Moraceae. In: Flora Costaricensis. Chicago: Fieldiana. Botany Series. p. 94-187.

Compton SG, Ball AD, Collinson ME, Hayes P, Rasnitsyn AP, Ross AJ. 2010.

Ancient fig wasps indicate at least $34 \mathrm{Myr}$ of stasis in their mutualism with fig trees. Biol Letters. 6:838-842.

Compton SG, Rasplus J-Y, Ware AB. 1994. African fig wasp parasitoid communities Oxford: Oxford University Press.

Cook JM, Rasplus J-Y. 2003. Mutualists with attitude: coevolving fig wasps and figs. Trends Ecol Evol. 18:241-248.

Cruaud A, Jabbour-Zahab R, Genson G, Couloux A, Peng Y-Q, Rong YD, Ubaidillah R, Pereira RAS, Kjellberg F, van Noort S, et al. 2011a. Out of Australia and back again: the world-wide historical biogeography of non-pollinating fig wasps (Hymenoptera: Sycophaginae). J Biogeogr. 38:209-225.

Cruaud A, Jabbour-Zahab R, Genson G, Kjellberg F, Kobmoo N, van Noort S, Yang D-R, Peng Y-Q, Ubaidillah R, Hanson PE, et al. 2011b. Phylogeny and 
evolution of life-history strategies in the Sycophaginae non-pollinating fig wasps (Hymenoptera, Chalcidoidea). BMC Evol Biol. 11:178.

Cruaud A, Rønsted N, Chantarasuwan B, Chou L-S, Clement WL, Couloux A, Cousins B, Genson G, Harrison RD, Hanson PE, et al. 2012. An extreme case of plant-insect co-diversification: figs and fig-pollinating wasps. Syst Biol. 61:1029-1047.

Elias LG. 2013. Morfologia de estruturas reprodutivas em vespas de figo (Chalcidoidea: Hymenoptera) com diferentes regimes alimentares $[\mathrm{PhD}$ thesis]. Ribeirão Preto (SP): USP.

Elias LG, Teixeira SP, Kjellberg F, Pereira RAS. 2012. Diversification in the use of resources by Idarnes species: bypassing functional constraints in the fig-fig wasp interaction. Biol J Linn Soc. 106:114-122.

Farache FHA, Cruaud A, Genson G, Pereira RAS, Rasplus J-Y. 2013. Taxonomic revision and molecular phylogeny of the fig wasp genus Anidarnes Bouček, 1993 (Hymenoptera, Sycophaginae). Syst Entomol. 38:14-34.

Farache FHA, Rasplus J-Y. 2014. Revision of the Australasian genus Pseudidarnes Girault, 1927 (Hymenoptera, Agaonidae, Sycophaginae). ZooKeys. 404:3170.

Galil J, Eisikowitch D. 1968. Flowering cycles and fruit types of Ficus sycomorus in Israel. New Phytol. 67:745-758.

Gerstaecker A. 1867. Beitrag zur Insekten-Fauna von Zanzibar, nach dem wahrend der Expedition des Barou v. d. Decken gesammelten Material zusammengestellt. Archiv Natur. 33:1-49.

Ghara M, Borges RM. 2010. Comparative life-history traits in a fig wasp community: implications for community structure. Ecol Entomol. 35:139-148.

Gibson GAP. 1997. Morphology and terminology. In: Annotated Keys to the Genera of Nearctic Chalcidoidea (Hymenoptera). Ottawa: National Research Council Press. p. 16-44.

Gordh G. 1975. The comparative external morphology and systematics of the Neotropical parasitic fig wasp genus Idarnes (Hymenoptera: Torymidae). Univ Kan Sci Bull. 50:389-455.

Heraty JM, Burks RA, Cruaud A, Gibson GAP, Liljeblad J, Munro JB, Rasplus JY, Delvare G, Jansta P, Gumovsky AV, et al. 2013. A phylogenetic analysis of the megadiverse Chalcidoidea (Hymenoptera). Cladistics. 29:466-542. 
Herrera CM. 1985. Determinants of plant-animal coevolution - the case of mutualistic dispersal of seeds by vertebrates. Oikos. 44:132-141.

Iturralde-Vinent MA, MacPhee RDE. 1996. Age and paleogeographical origin of Dominican amber. Science. 273:1850-1852.

Kjellberg F, Jousselin E, Bronstein JL, Patel A, Yokoyama J, Rasplus J-Y. 2001. Pollination mode in fig wasps: the predictive power of correlated traits. P Roy Soc B-Biol Sci. 268:1113-1121.

Kjellberg F, Jousselin E, Hossaert-McKey M, Rasplus J-Y. 2005. Biology, ecology, and evolution of fig-pollinating wasps (Chalcidoidea, Agaonidae). In: Biology, ecology and evolution of gall-inducing arthropods: volume 2. New Hampshire: Science Publishers, Inc. p. 539-572.

Latreille PA. 1817. Les crustacés, les arachnides et les insectes. In: Le règne animal distributé d'après son organization: pour servir de base à l'histoire naturelle des animaux et d'introduction à anatomie comparée. 1st ed. Paris. p. 653.

Linnaeus C. 1758. Systema Naturae per regna tria naturae, secundum classes, ordines, genera, species, cum characteristibus, differentiis, synonymis, locis. 10th ed. Holmiae [Stockholm]: Laurentii salvii.

Marussich WA, Machado CA. 2007. Host-specificity and coevolution among pollinating and nonpollinating New World fig wasps. Molecular Ecology. 16:1925-1946.

Peñalver E, Engel MS, Grimaldi DA. 2006. Fig Wasps in Dominican Amber (Hymenoptera: Agaonidae). Am Mus Novit. 3541:1-16.

$\mathrm{R}$ : A language and environment for statistical computing [available at: http://www.Rproject.org/ ]. 2015. Vienna, Austria: R Foundation for Statistical Computing. Ramírez W. 1974. Coevolution of Ficus and Agaonidae. Annals Mo Bot Gdn. 61:770-780.

Ramírez W. 1978. Evolution of mechanisms to carry pollen in Agaonidae (Hymenoptera Chalcidoidea). Tijd Entomol. 121:279-293.

Segar ST, Dunn DW, Darwell CT, Cook JM. 2013. How to be a fig wasp down under: The diversity and structure of an Australian fig wasp community. Acta Oecol. 57:17-27.

Shanahan M, So S, Compton SG, Corlett R. 2001. Fig-eating by vertebrate frugivores: a global review. Biological reviews of the Cambridge Philosophical Society. 76:529-572. 
van Noort S, Compton SG. 1996. Convergent evolution of agaonine and sycoecine (Agaonidae, Chalcidoidea) head shape in response to the constraints of host fig morphology. J Biogeogr. 23:415-424.

Walker F. 1843. Descriptions of Chalcidites discovered in St. Vincent's Isle by the Rev. Lansdown Guilding. Ann Mag Nat Hist. 12:46-49.

Walker F. 1846. List of the specimens of Hymenopterous insects in the collection of the British Museum. Part 1 Chalcidites London.

Weiblen GD. 2004. Correlated evolution in fig pollination. Syst Biol. 53:128-139.

West SA, Herre EA. 1994. The ecology of the New World fig-parasitizing wasps Idarnes and implications for the evolution of the fig-pollinator mutualism. $\mathrm{P}$ Roy Soc B-Biol Sci. 258:67-72.

Yoder MJ, Mikó I, Seltmann KC, Bertone MA, Deans AR. 2010. A gross anatomy ontology for Hymenoptera. Plos One. 5:e15991.

Zhen W-Q, Huang D-W, Xiao J-H, Yang D-R, Zhu C-D, Xiao H. 2005. Ovipositor length of three Apocrypta species: effect on oviposition behavior and correlation with syconial thickness. Phytoparasitica. 33:113-120. 
Table 1: Models used to explain fig wasp characters as a function of fig diameter $(\mathrm{N}=$ 31 pairs of species).

\begin{tabular}{lcccc}
\hline Model & Slope & $\mathrm{R}^{2}$ & $t$ value & Prob. \\
\hline Ovipositor sheath length $\sim$ Fig size & $2.9 \pm 0.3$ & 0.76 & 9.69 & $<10^{-9}$ \\
Body length $\sim$ Fig size & $0.5 \pm 0.06$ & 0.69 & 8.28 & $<10^{-8}$ \\
Ovipositor / Body $\sim$ Fig size & $1.3 \pm 0.15$ & 0.70 & 8.43 & $<10^{-8}$ \\
\hline
\end{tabular}



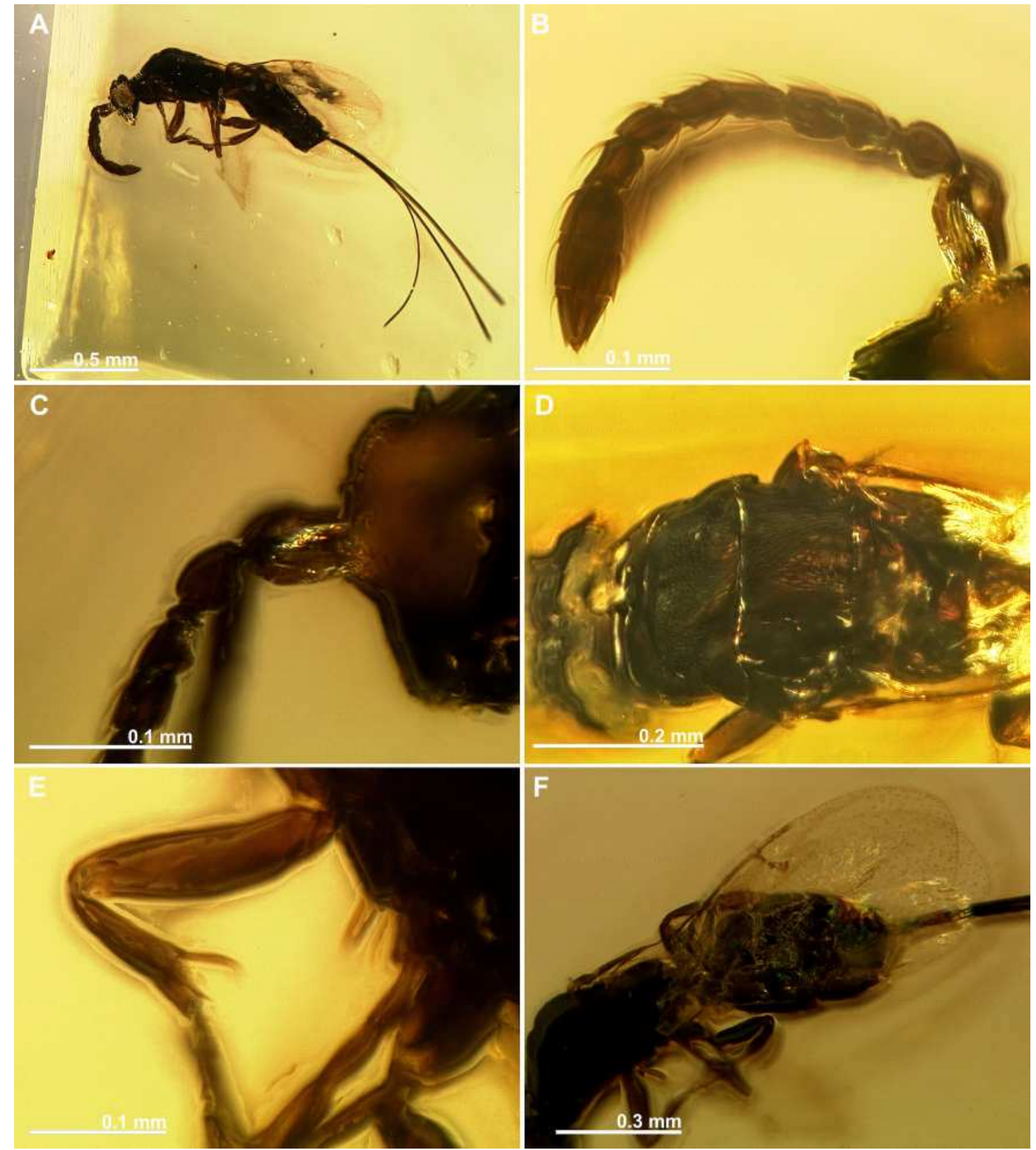

Figure 1: Idarnes thanatos sp. nov. Female. A habitus in lateral view $\mathbf{B}$ antenna $\mathbf{C}$ detail of antenna $\mathbf{D}$ mesosoma in dorsal view $\mathbf{E}$ detail of profemur and protibia $\mathbf{F}$ wings. 


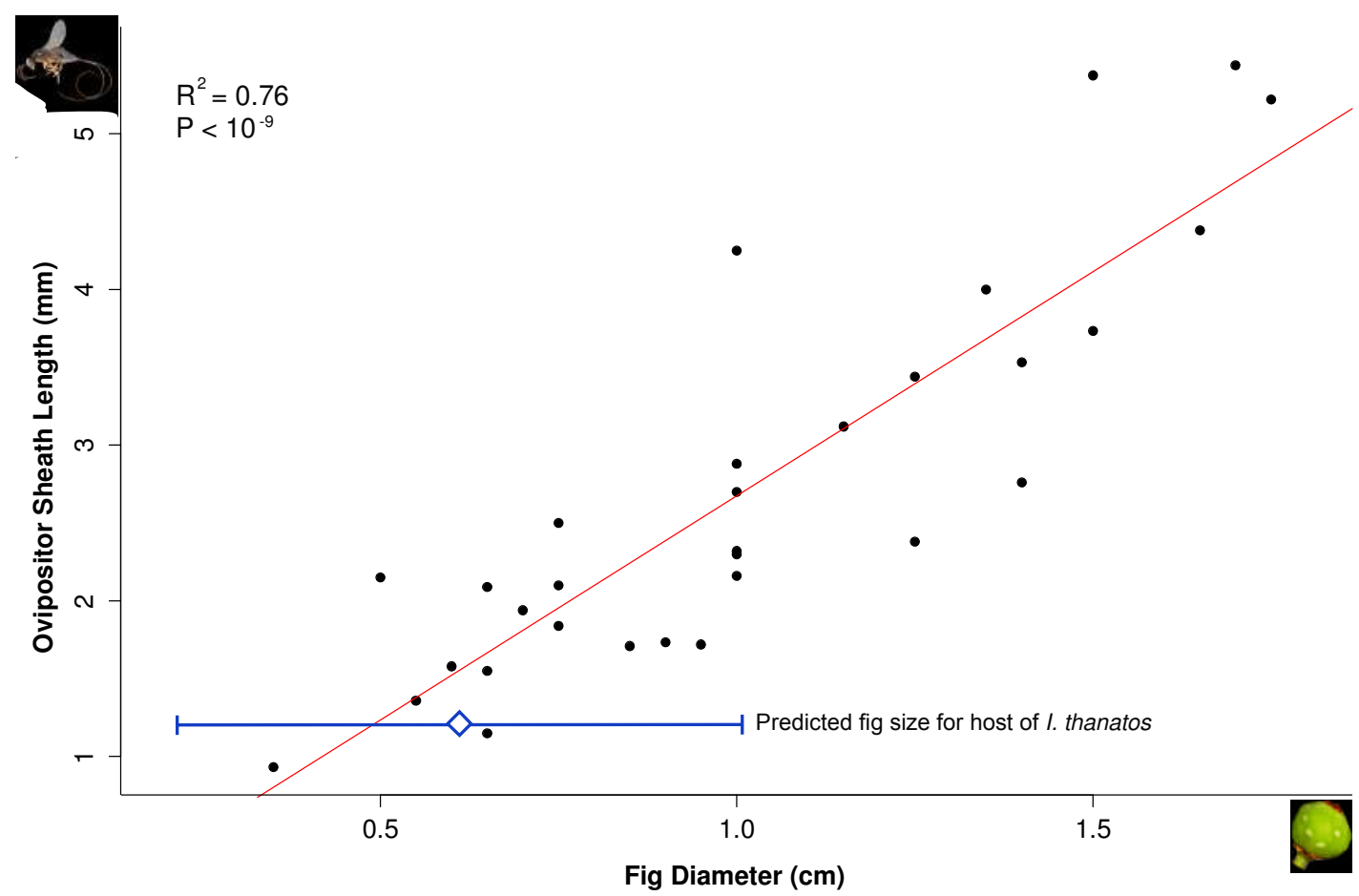

Figure 2: Linear regression between Idarnes carme sp. gp. ovipositor sheath lengths and median host fig diameters. Lines represent fitted model (red) and fig diameter \pm 95\% CI (blue) for a $1.2 \mathrm{~mm}$ ovipositor sheath length, which represents the ovipositor sheath length of I. thanatos sp.n. Each point represents a different fig wasp species and the fig diameter of its host species.

\section{Supplementary files}

Supplementary file 1: Original amber piece before extraction of the specimen.

Supplementary file 2: Dataset including measures for Idarnes species and their host fig diameters used in linear regression analyses. 